\title{
Monitoring recent lake level variations on the Tibetan Plateau using CryoSat-2 SARIn mode data
}

\author{
Jiang, Liguang; Nielsen, Karina; Andersen, Ole Baltazar; Bauer-Gottwein, Peter
}

Published in:

Journal of Hydrology

Link to article, DOI:

10.1016/j.jhydrol.2016.11.024

Publication date:

2017

Document Version

Peer reviewed version

Link back to DTU Orbit

Citation (APA):

Jiang, L., Nielsen, K., Andersen, O. B., \& Bauer-Gottwein, P. (2017). Monitoring recent lake level variations on the Tibetan Plateau using CryoSat-2 SARIn mode data. Journal of Hydrology, 544, 109-124.

https://doi.org/10.1016/j.jhydrol.2016.11.024

\section{General rights}

Copyright and moral rights for the publications made accessible in the public portal are retained by the authors and/or other copyright owners and it is a condition of accessing publications that users recognise and abide by the legal requirements associated with these rights.

- Users may download and print one copy of any publication from the public portal for the purpose of private study or research.

- You may not further distribute the material or use it for any profit-making activity or commercial gain

- You may freely distribute the URL identifying the publication in the public portal 
3 Liguang Jianga, ${ }^{\mathrm{a},}$, Karina Nielsen ${ }^{\mathrm{b}}$, Ole B. Andersen ${ }^{\mathrm{b}}$, Peter Bauer-Gottwein ${ }^{\mathrm{a}}$

\section{Monitoring recent lake level variations on the Tibetan Plateau using CryoSat-2}

\section{SARIn mode data}

${ }^{a}$ Department of Environmental Engineering, Technical University of Denmark, Bygningstorvet 115, 2800 Kgs. Lyngby, Denmark

${ }^{b}$ National Space Institute, Technical University of Denmark, Elektrovej 327, 2800 Kgs. Lyngby, Denmark

${ }^{*}$ Corresponding author. E-mail address: ljia@env.dtu.dk (L. Jiang).

\section{Abstract}

Lakes on the Tibetan Plateau (TP) are of great interest due to their value as water resources but also as an important indicator of climate change. However, in situ data in this region are extremely scarce and only a few lakes have gauge measurements. Satellite altimetry has been used successfully to monitor lake levels. In this study, Cryosat-2 SARIn mode data over the period 2010 to 2015 are used to investigate recent lake level variations. The estimated water levels of the 70 largest lakes $\left(>100 \mathrm{~km}^{2}\right)$ on the TP show that 48 lakes reveal a rising trend (avg. $0.28 \pm 0.06 \mathrm{~m} / \mathrm{yr}$ ) while the other 22 show a slightly decreasing trend (avg. $-0.10 \pm 0.04$ $\mathrm{m} / \mathrm{yr}$ ). To compare with the change rates during 2003-2009, ICESat data which cover 42 of the 70 lakes are also used. When combining the data, the results show that during the period of 2003-2015, 28 lakes maintained a rising trend and the change rates are comparable. Lakes in the northern part of the TP experienced pronounced rising (avg. $0.37 \pm 0.10 \mathrm{~m} / \mathrm{yr}$ ), while lakes in southern part were steady or decreasing even in glaciated basins with high precipitation. 
Factor analysis indicates that driving factors for lake change are variable due to high spatial heterogeneity. However, autumn/winter temperature plays an important role in lake level change. These results demonstrate that lakes on the TP are still rapidly changing under climate change, especially in northern part of the TP, but the driving factors are variable and more research is needed to understand the mechanisms behind observed changes.

Keywords: Lake Level; Tibetan Plateau; Altimetry; Cryosat-2; SARIn

\section{Introduction}

The Tibetan Plateau (TP), with an average elevation of more than 4000 m-amsl and an area of approximately 2.5 million $\mathrm{km}^{2}$, is China's largest and the world's highest highland. The TP plays a significant role in the regional and global climate system due to its large area and high altitude(Wu et al., 2007; Yanai and Li, 1994). It is important for Asian monsoon development and water-energy cycles (Molnar et al., 2010). The TP has the largest ice mass outside the Arctic and Antarctic regions. The snow and ice masses feed many large rivers which provide water to more than 1.4 billion people (Immerzeel et al., 2010). The TP is characterized by thousands of lakes, which cover an area of $41831 \mathrm{~km}^{2}$ (Wan et al., 2014). Therefore, the TP is also called the “Asian water tower” (Lu et al., 2005). Besides their value as water resources, lakes are critical landscape units which play an important role in the land surface energy cycle and thus impact the regional climate and water circulation. However, most of the lakes have experienced great changes during the past three decades and are still changing rapidly due to climate change. The investigation of Wan et al. (Wan et al., 2014) indicated that about 30 new lakes appeared and 5 existing lakes have dried up and vanished in the period of 1975-2006. In addition, most of the 
largest 13 lakes (> $500 \mathrm{~km}^{2}$ ) experienced drastic changes. For instance, Siling Co has expanded by $600 \mathrm{~km}^{2}$ accounting for about 26\% of total area since 1976 (Zhou et al., 2015), while the size of Qinghai Lake first decreased by $231 \mathrm{~km}^{2}$ and then expanded by $134 \mathrm{~km}^{2}$ during 19732013 (Shen et al., 2013).

Satellite radar altimetry has been a successful technique and widely used to monitor lake level variations (Berry et al., 2005; Birkett, 1995; Crétaux et al., 2016; Crétaux and Birkett, 2006; Gao et al., 2013; Kleinherenbrink et al., 2015; Liao et al., 2014; Song et al., 2014, 2015a, 2015b, 2015c). It has become a very important alternative data source to in situ observations, especially in remote areas where in situ data are not available, e.g. the TP. Among several conventional radar satellite missions (Topex/Poseidon, Jason, ERS, ENVISAT, etc.), the new generation of radar altimetry, CryoSat-2 has some advantages. The CryoSat-2 mission, launched in April 2010, has been operational for 6 years in April 2016. Cryosat-2 features a delay/Doppler technology. Its primary instrument, the Ku-Band Synthetic Aperture Interferometric Radar Altimeter (SIRAL), has three measurement modes: low resolution mode (LRM), synthetic aperture radar mode (SAR) and SAR interference mode (SARIn). Additionally, CryoSat-2 has a repeat period of 369 days and an inclination of 92 degrees, thus it covers a larger area than previous missions. Meanwhile, it has a subcycle of 30 days, that is to say, the density of ground tracks is high, thus many lakes are visited (European Space Agency and Mullar Space Science Laboratory, 2012; Kleinherenbrink et al., 2014; Nielsen et al., 2015).

The TP is a crucial testing ground for application of altimetry on inland water because of its numerous lakes (Fig. 1) and the lack of gauge-based observations. Ice, Cloud, and land Elevation / Geoscience Laser Altimeter System (ICESat/GLAS) demonstrated its value in 
monitoring lake level change (Phan et al., 2012; Song et al., 2013; Zhang et al., 2011). In the past few years, a growing number of studies have used ICESat/GLAS to retrieve lake level time series (Li et al., 2014; O’Loughlin et al., 2016; Phan et al., 2012; Wang et al., 2013; Zhang et al., 2011). Nevertheless, the application of CryoSat-2 in hydrology community is still in its infancy. Kleinherenbrink et al. (2015) first presented the application of CryoSat-2 SARIn mode data over the period February 2012 to January 2014 to monitor lakes on the TP. However, more research is needed to explore the full potential of Cryosat-2 in monitoring of inland water level. In this paper, we investigate water level change of large lakes $\left(>100 \mathrm{~km}^{2}\right)$ on the TP using CryoSat-2 SARIn mode data of 2010-2015. We apply the Narrow Primary Peak Threshold (NPPT) retracker (Jain et al., 2015), which has proven to provide valid results for inland water applications (Nielsen et al., 2015; Villadsen et al., 2016). In terms of height precision, the NPPT retracker is seen to outperform the ESA L2 data (Jain et al., 2015), but for studies of lake level change there is only in-significant difference depending on the choice of NPPT versus L2 retracker. Finally we estimate the along-track mean water level for each pass using a robust method (Nielsen et al., 2015).Lake level changes are compared during two periods of 20032009 and 2010-2015, and the potential causes of lake change are investigated. 


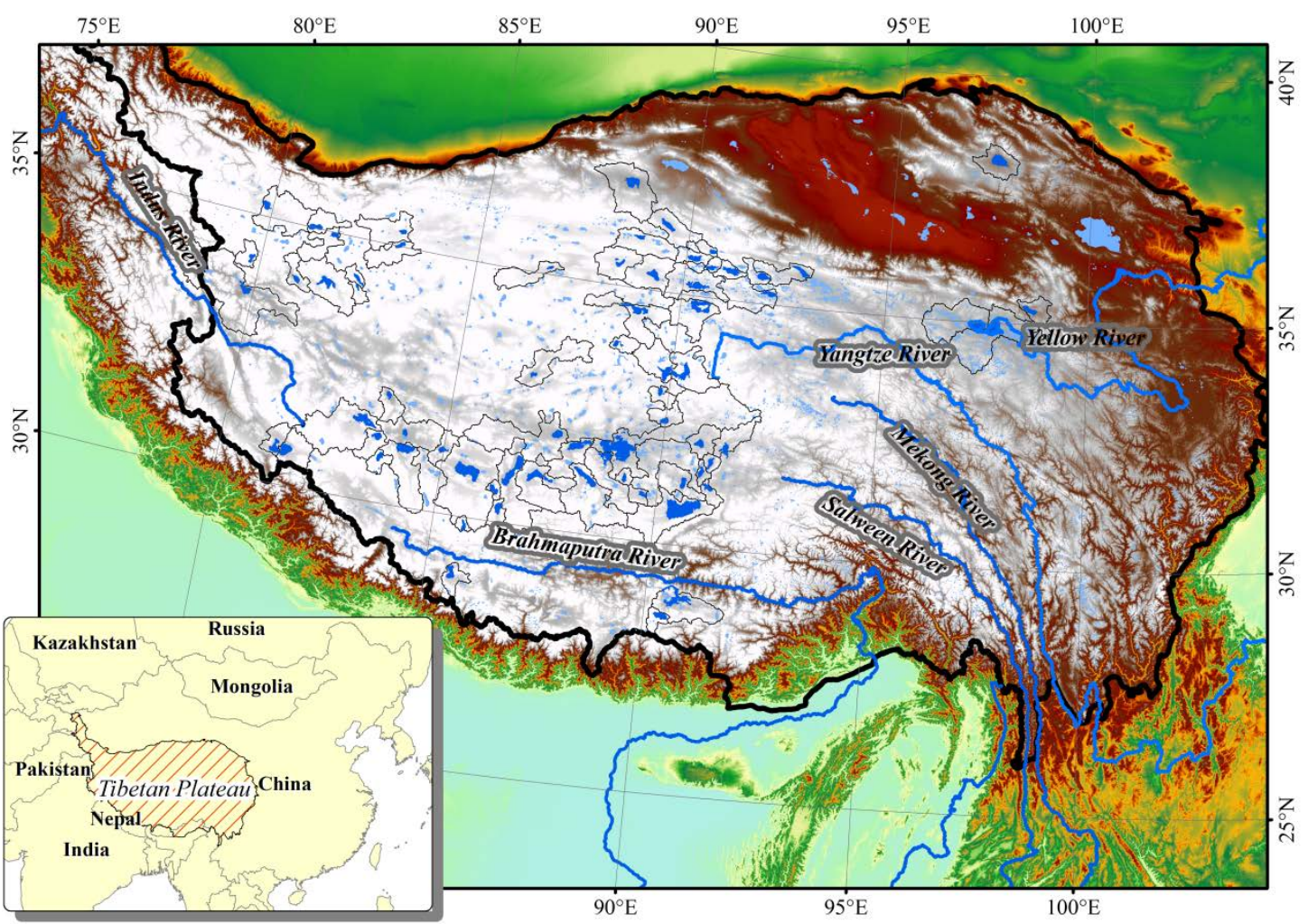

Figure 1: Topographic map of the Tibetan Plateau and distribution of large rivers and lakes (studied lakes are shown in blue)

\section{Data and methods}

\subsection{Water mask}

Landsat 8 OLI and Landsat 7 ETM+ images were downloaded via the United States Geological Survey (USGS) EarthExplorer (http://earthexplorer.usgs.gov/) to delineate the lake masks. The acquisition dates of all images are between May to December of 2014 to get high quality images over lakes. In total, 34 scenes of Landsat 8 OLI and 18 of Landsat ETM+ were used to derive the lake mask. Considering the efficiency and quality of different methods, a threshold-based approach was used combined with visual examination. The thresholds of DN 35-40 and 5000-5600 was used to extract the lake body with band 5 (Landsat 7) and band 6 (Landsat 8) depending on the date of image acquisition. 


\subsubsection{Lake level estimation}

The ESA level $1 \mathrm{~b}$ baseline B data product in SARIn mode was used as input. The waveforms were retracked using the Narrow Primary Peak Threshold (NPPT retracker (Jain et al., 2015)). The range $\mathrm{R}$ is computed as:

$$
R=R_{w d}+R_{r}+R_{g c}
$$

where $\mathrm{R}_{\mathrm{wd}}$ is the window delay; $\mathrm{R}_{\mathrm{r}}$ is the retracker correction and $\mathrm{R}_{\mathrm{gc}}$ is geophysical corrections including ionosphere, wet and dry troposphere, solid earth tide, ocean loading tide, and pole tide. Both $\mathrm{R}_{\mathrm{wd}}$ and $\mathrm{R}_{\mathrm{gc}}$ are available in the $\mathrm{L} 1 \mathrm{~b}$ data product.

In SARIn mode, the SIRAL altimeter, employees both antennas, which makes it possible to detect the origin of the echo. Hence, it is possible to estimate the range correction, which occurs, when the reflector is not at the nadir position. The range correction is here estimated according to Armitage and Davidson (2014). The lakes on the TP are completely or partly frozen during parts of the year, which might influence the ranges (Sørensen et al., 2011).

Finally, the surface elevations H with respect to the Earth Gravitational Model of 2008 geoid (EGM2008) are obtained using the following expression:

$$
H=h-R-N,
$$

where $\mathrm{h}$ is the satellite altitude and $\mathrm{N}$ is the geoid height with respect to the ellipsoid. Since Cryosat-2 is overflying the lakes at different positions potential residual geoid errors might be present in the constructed time series. 


\subsubsection{Times series construction}

After extraction by lake masks, the water level time series for 70 lakes were estimated using the "R" package tsHydro (https://github.com/cavios/tshydro). The core of tsHydro is a state-space model, where the process model is described by a simple random walk and the observation model is described by the true water level and an error term. The error structure is modelled by a mixture between Normal and Cauchy distributions. The distribution has heavier tails compared to a pure Normal distribution, which makes the model robust against erroneous observations. The model is detailed in Nielsen et al. (2015). Figure 2 illustrates the water level estimation processes.

\subsection{ICESat}

The ICESat was a laser altimeter mission that operated during 2003-2009. It was used to compare the lake level variations from Cryosat-2. The ICESat data were obtained from IWSH (http://data.bris.ac.uk/data/dataset/15hbqgewcrti51hmzp69bi4gky) (O’Loughlin et al., 2016), which already includes geodetic and atmospheric corrections, and outlier removal. Before extracting data by our mask, the height is converted from EGM96 to EGM2008 to be consistent with Cryosat-2 data.

\subsection{Trend estimation and storage change calculation}

To estimate the overall change trend of lake levels, a linear model is used. The trend (or rate of lake level change) is estimated by fitting the following equation to the observations using a least squares method:

$$
y=\beta_{0}+\beta_{1} t
$$


135

where $y$ is the lake level time series; $\beta_{0}$ and $\beta_{1}$ are the parameters to be estimated, and $t$ is the time (decimal year). $\beta_{1}$ is the trend in units of meter per year.

The formula for calculating the storage change is applied by assuming that the volume is a circular cone (Taube, 2000):

$$
V=\frac{1}{3}\left(H_{2}-H_{1}\right)\left(A_{1}+A_{2}+\sqrt{A_{1} \times A_{2}}\right) / 1000
$$

where $\mathrm{V}$ is the storage change $\left(10^{9} \mathrm{~m}^{3}\right) ; \mathrm{H}_{1}$ and $\mathrm{H}_{2}$ are the level $(\mathrm{m})$ at the start and end of a period, and $\mathrm{A}_{1}$ and $\mathrm{A}_{2}$ are corresponding lake areas $\left(\mathrm{km}^{2}\right)$.

\subsection{Regression analysis}

Factor analysis is performed to find the underlying relationship between lake level change and different factors. Both weighted linear regression and multiple linear regression are used in this context.

Instead of minimizing the sum of squared residuals (SSR),

$$
S S R=\sum_{i=1}^{n}\left[\beta_{1 i}-\left(\alpha_{0}+\alpha_{1} x_{i}\right)\right]^{2}
$$

we minimize a weighted sum of squared residuals (WSSR),

$$
W S S R=\sum_{i=1}^{n} w_{i}\left[\beta_{1 i}-\left(\alpha_{0}+\alpha_{1} x_{i}\right)\right]^{2}
$$

and we use weight $\mathrm{w}$,

$$
w=\frac{1}{\sigma^{2}}
$$

where $\mathrm{x}$ is any factor (e.g. latitude, temperature/precipitation change rate, etc.); $\alpha_{0}$ and $\alpha_{1}$ are the parameters to be estimated; $\beta_{1}$ and $\sigma$ are trend and standard error of the trend, respectively, obtained from fitting Eq. (3), and $\mathrm{n}$ is the number of lakes. 
155

156

157

158

159

160

161

162

163

164

165

166

167

168

169

170

171

172 173 minimum and maximum temperatures. The Randolph Glacier Inventory 5.0 174 (http://www.glims.org/RGI/rgi50 dl.html) is used to calculate the glacier ratio.

175

\subsection{Auxiliary data}

The HydroBASINS product (http://www.hydrosheds.org/page/hydrobasins) was used as reference data to delineate lake basins. To ensure the accuracy of each lake basin, the watersheds from the HydroBASINS dataset were visually checked with SRTM DEM. Some debris polygons were merged and some lake basins embedded in bigger basins were delineated separately. All basin-averaged parameters, i.e. temperature, precipitation, supply coefficient (basin area minus lake area, divided by lake area), glacier ratio (glacier area divided by the difference between basin area and lake area), snow/rain ratio, basin elevation are calculated using this basin dataset.

Monthly precipitation and temperature data for 1985-2014 are obtained from the China Meteorological Data Sharing Service System (http://data.cma.cn/), and also 30 year-averaged daily precipitation and temperature data, which is used to calculate snow/rain ratio depending on the corresponding temperature. The gridded dataset at $0.5^{\circ} \times 0.5^{\circ}$ spatial resolution is produced by the National Meteorological Information Center (NMIC) of the China Meteorological Administration (CMA), by interpolating observations of 2472 stations (including national Reference Climate Network stations, Basic Meteorological Network stations and national Ordinary Meteorological Network stations) using the thin plate spline method. We calculated the climate normals and change rate for precipitation and mean,

Lake area of 2010 is obtained from Third Pole Environment database 

change is calculated using Eq. (4).

178

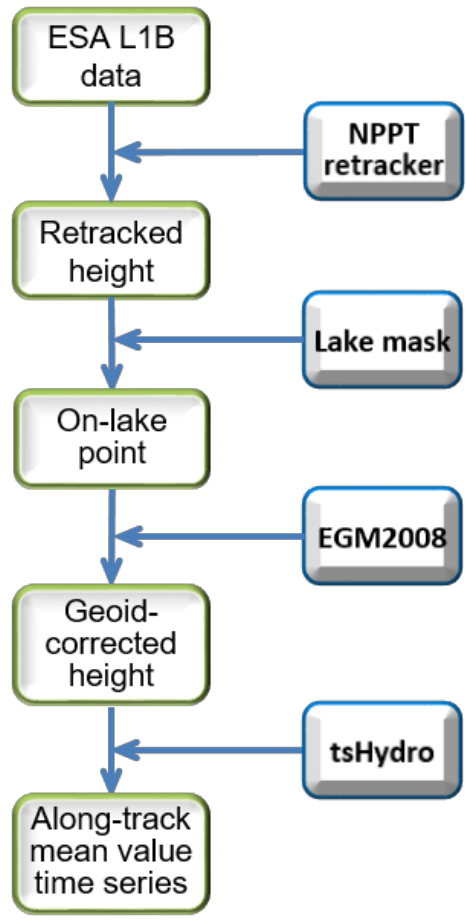

Figure 2: Flowchart of water level estimation

\section{Results}

\subsection{Overview of lake level change}

In total, 70 lakes having at least 10 passes are considered in this study and the average length of time series is 34 (Table 1). Our results of lake level change rate are depicted in Figure 2. It is clear that, most lakes show a significant increasing trend. To be specific, 48 lakes reveal rising trend (30 are significant at 95\% Confidence Level (CL)) with mean rate of $0.28 \mathrm{~m} / \mathrm{yr}$ while the other 22 show falling trend (3 are significant at 95\% CL) with mean rate of $-0.10 \mathrm{~m} / \mathrm{yr}$. Lakes are grouped into different sub-regions according to their geography, topography and climatic characteristics (Table 2 \& Fig. 3). 


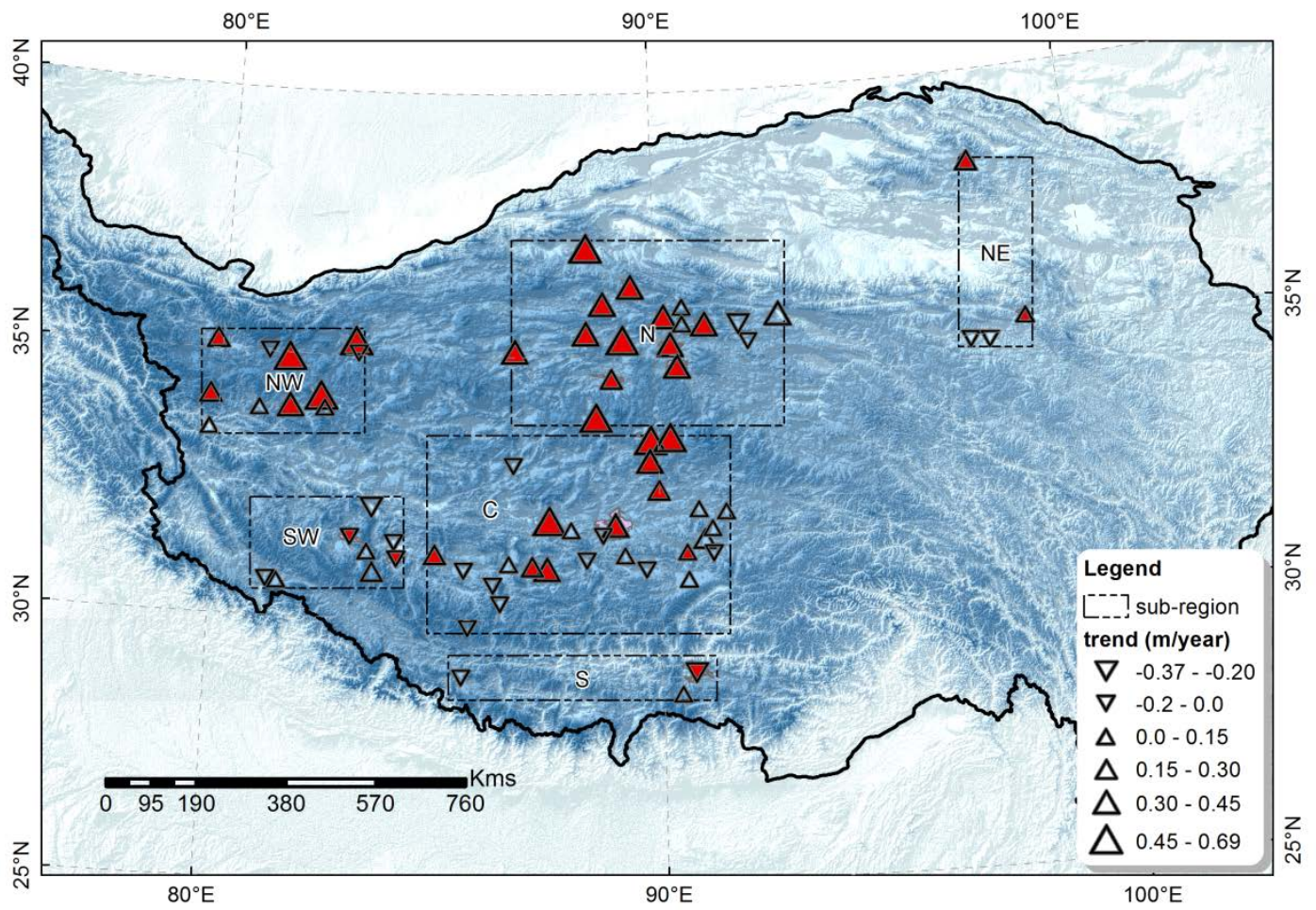

190 Figure 3: Spatial distributions of lake level changing trends. Upward/downward 191 triangles represent positive/negative trends. Solid-red triangles indicate significant trends at the $95 \%$ confidence level

Sub-region NW: In the northwestern part of the TP, characterized by higher elevation (avg.

$5232 \mathrm{~m}$ ), cold and arid climate, dominated by the westerly (Yao et al., 2013). In this region,

glacier and snow cover are widely distributed. Most lakes are fed by glacier- and snow-melt water (Wang and Dou, 1998). Seven of nine lakes show a rising trend. Bangdag Co, Memar Co and Xianshui Hu are the top three with rising rate in the order of $0.7 \mathrm{~m} / \mathrm{yr}$ (Fig. 4). Only Gozha 

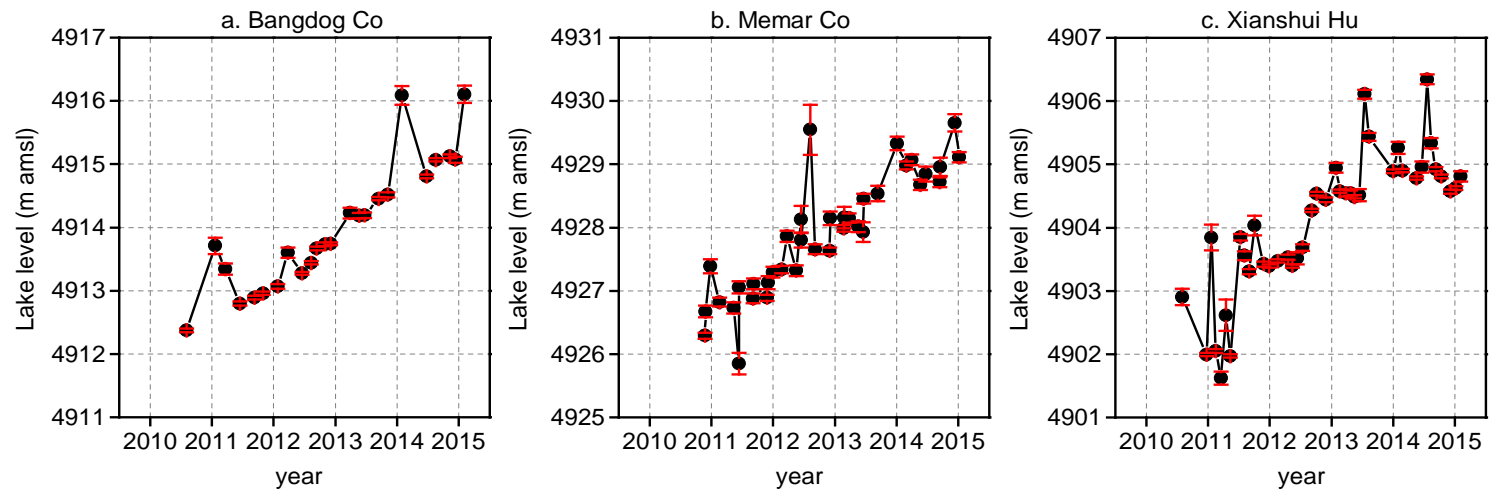

201

202

203
Sub-region N: This sub-region lies in the Hoh Xil region, which is the so-called “No-man’s

land”, known for its harsh environment, i.e., low temperature, strong wind and low oxygen content. In this region, lakes are distributed densely and most of them are endorheic lakes. As listed in Table 2, $88 \%$ of the lakes were expanding at an average rate of $0.374 \mathrm{~m} / \mathrm{yr}$. Aqqikkol lake level increased at the largest rate of $0.681 \mathrm{~m} / \mathrm{yr}$ and is now the second largest lake by area in this sub-region. The largest lake, Ulan Ul lake, also exhibited a significant trend of 0.329 $\mathrm{m} / \mathrm{yr}$. The increase in water storage in this sub-region is substantial considering their large areas (avg. $300 \mathrm{~km}^{2}$ ) and rising rates. It should be noted that most of the lakes in this sub-region show a period of rapid level change (0.4 - $1.1 \mathrm{~m})$ during March to October 2012, and most of these lakes show a steady state in recent two years (Fig. 5). 

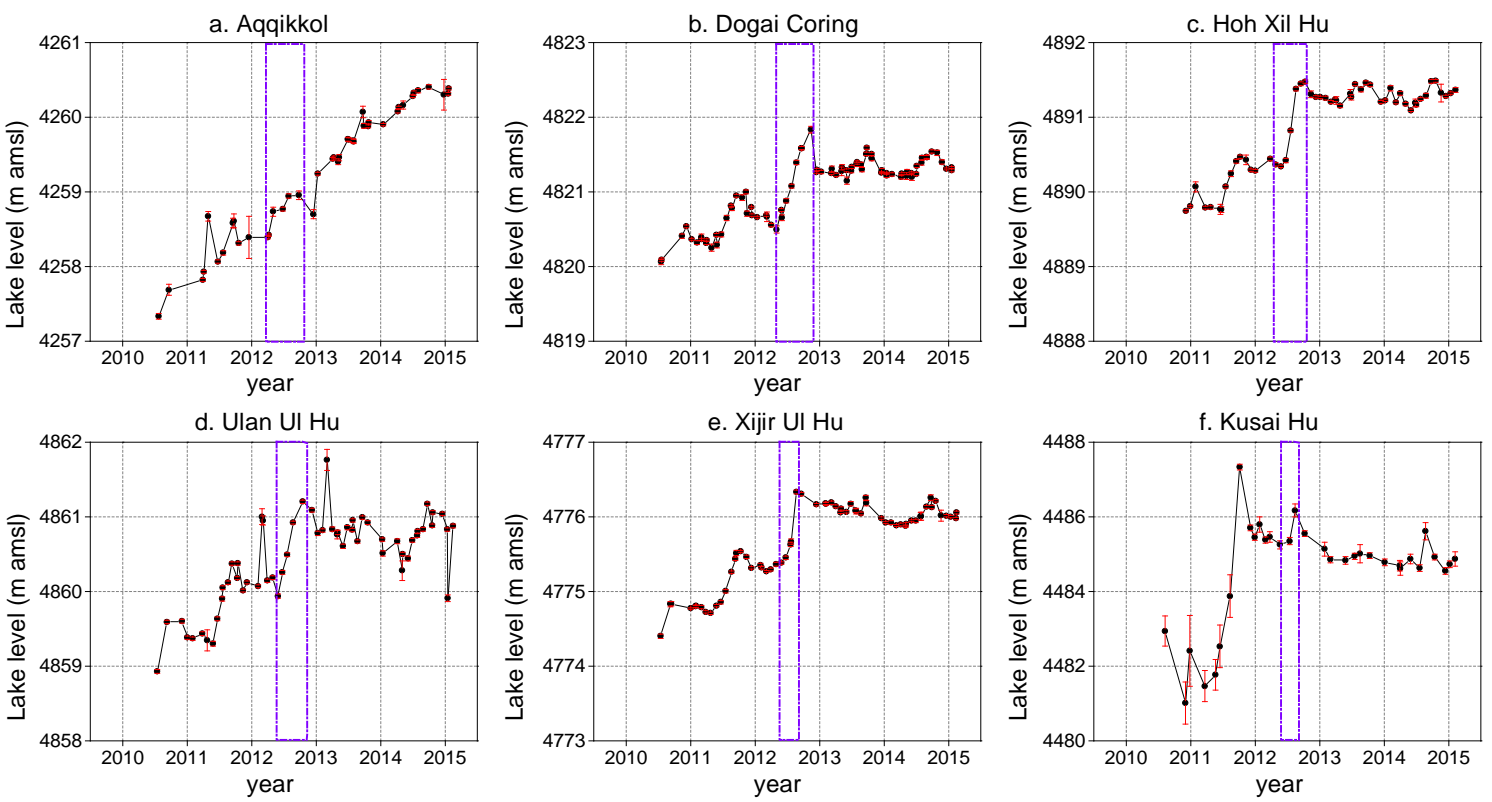

Figure 5: Time series of six lakes water level in sub-region $\mathrm{N}$ with pronounced sharp increase in 2012

Sub-region SW: In this region, all lakes were relatively steady. Even though decreasing trends are dominant, the change rates are low $(<0.164 \mathrm{~m} / \mathrm{yr})$. average increasing and declining rates are 0.22 and $-0.072 \mathrm{~m} / \mathrm{yr}$, respectively. Dorsoidong Co

223 and Migriggyangzham Co experienced the fastest rising. The level increase exceeds $2 \mathrm{~m}$ for

224 both lakes (Fig. 6). Siling Co shows an abrupt rising in 2011 and is now larger than Nam Co,

225 being the second largest salt lake in China and it is still rising at the rate of $0.374 \mathrm{~m} / \mathrm{yr}$ (Fig. 6).

Nine lakes are slightly decreasing, such as Zhari Namco (Fig. 6). 

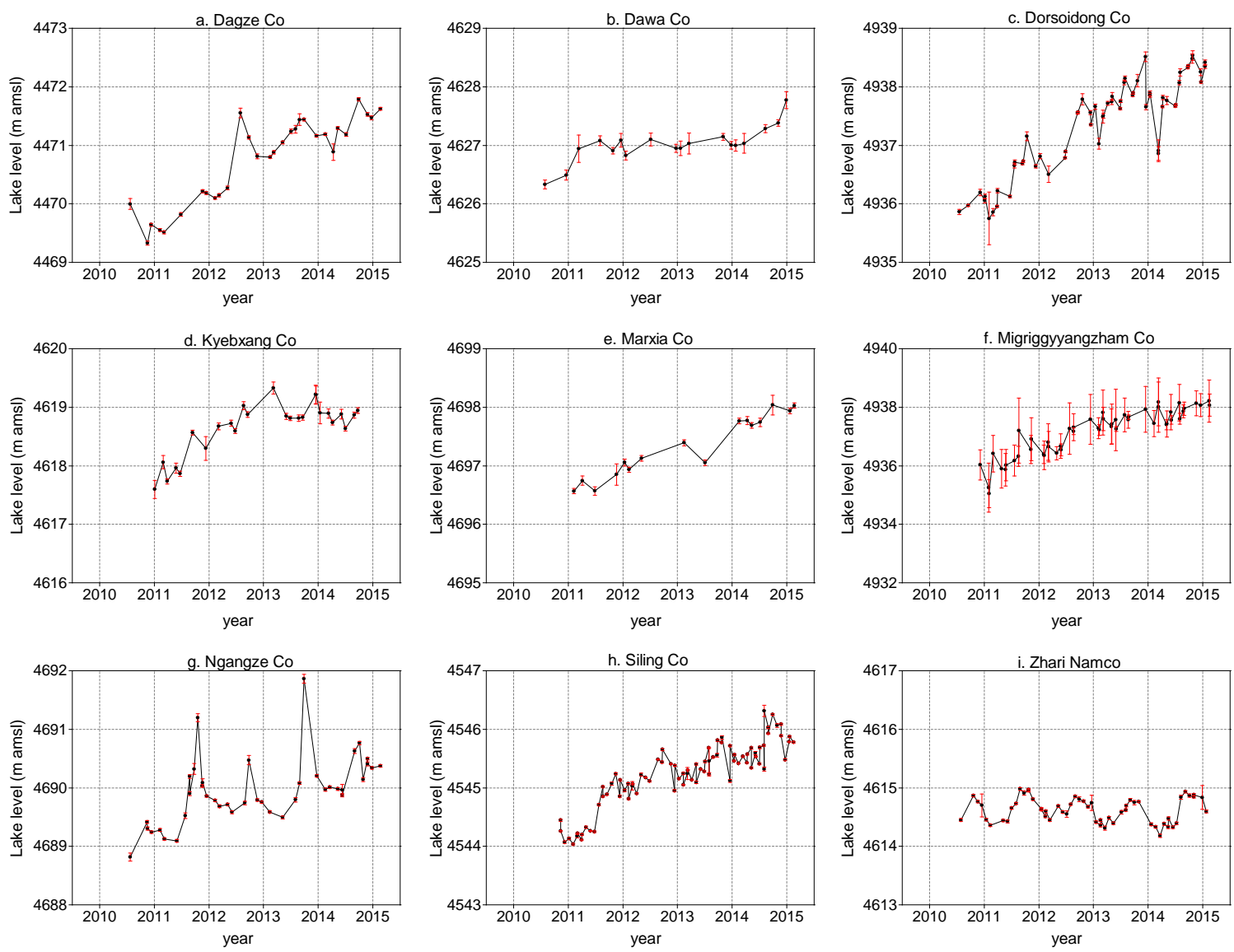

Figure 6: Time series of water level from nine lakes in sub-region C

Sub-region S: This region lies in Yarlung Tsangpo (Brahmaputra) river basin. Peiku Co

230 and Yamdrok Lake show a clear decreasing trend, while Puma Yumco has a slight rising trend.

231 Yamdrok, the largest in southern TP, had been decreasing at $-0.366 \mathrm{~m} / \mathrm{yr}$.

232 Sub-region NE: This is the three-rivers source region and Qaidam Basin in the Qinghai province.

233 In this region, lakes were almost steady (Fig. 7). Sister lakes Ngoring and Gyaring show a slight

234 decreasing trend, at rates of -0.06 and $-0.02 \mathrm{~m} / \mathrm{yr}$. Both Ngoring and Gyaring have a large

235 fluctuation in 2012. Comparatively, Hala Hu and Doggi Conag were rising at 0.16 and 0.11 m/yr. 

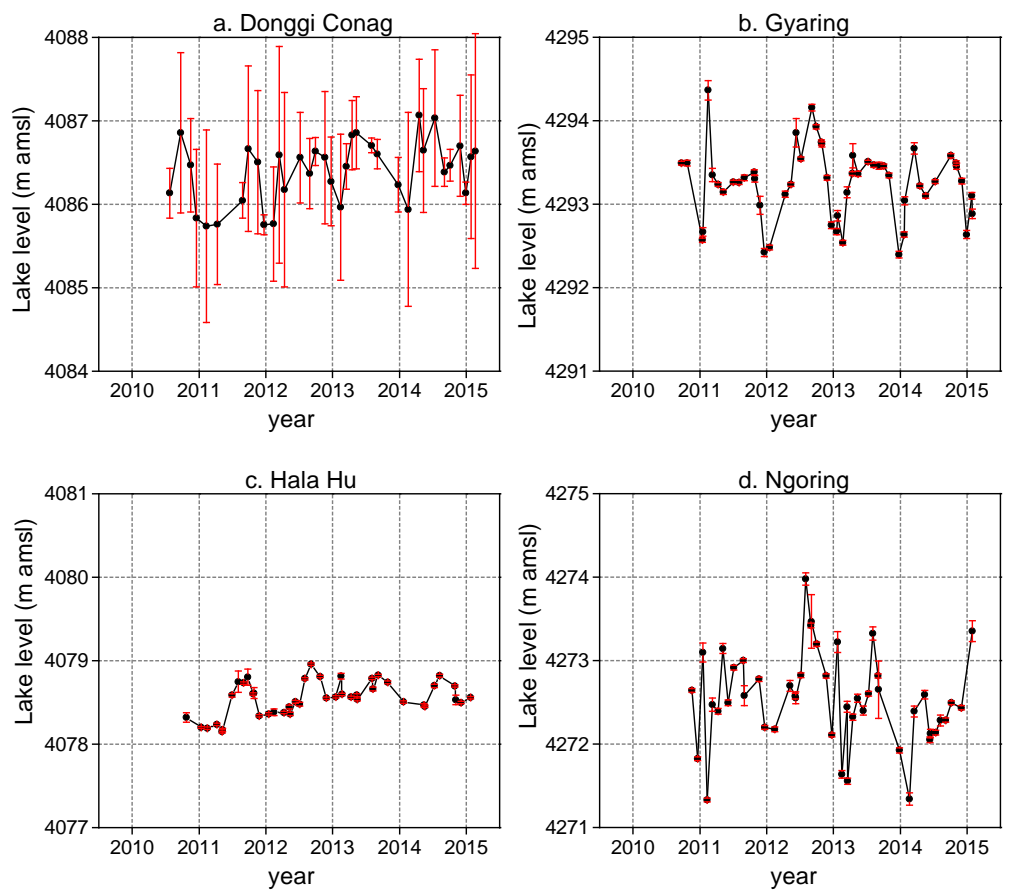

Figure 7: Lake level changes of Doggi Conag, Gyaring, Hala Hu and Ngoring

In summary, lake rising is the dominant trend despite some lakes showing a slight decrease.

Spatially, lakes in sub-region NW are rising faster than that in sub-region NE, and also rising trends are very significant in the northern part of the TP.

\subsection{Lake level and storage change}

Lake level changes from 2010 to 2015 were calculated as well as the corresponding storage changes (Fig. 8). The rising trend in lake levels is significant. Nine (13\%) lakes rose beyond 2 m, among which Bangdag Co even rose by $3.73 \mathrm{~m}$. Regionally, lakes in sub-region NW and N had a significant level increment with an average of 1.0 and $1.26 \mathrm{~m}$, respectively. Comparatively, for lakes that were declining, the magnitude of the trend is small. Only 4 lakes exhibited a decline of the order of $-1.2 \mathrm{~m}$ while the others (82\%) just within $1 \mathrm{~m}$. Besides, these lakes were relatively small in area and thus the storage loss was limited. 

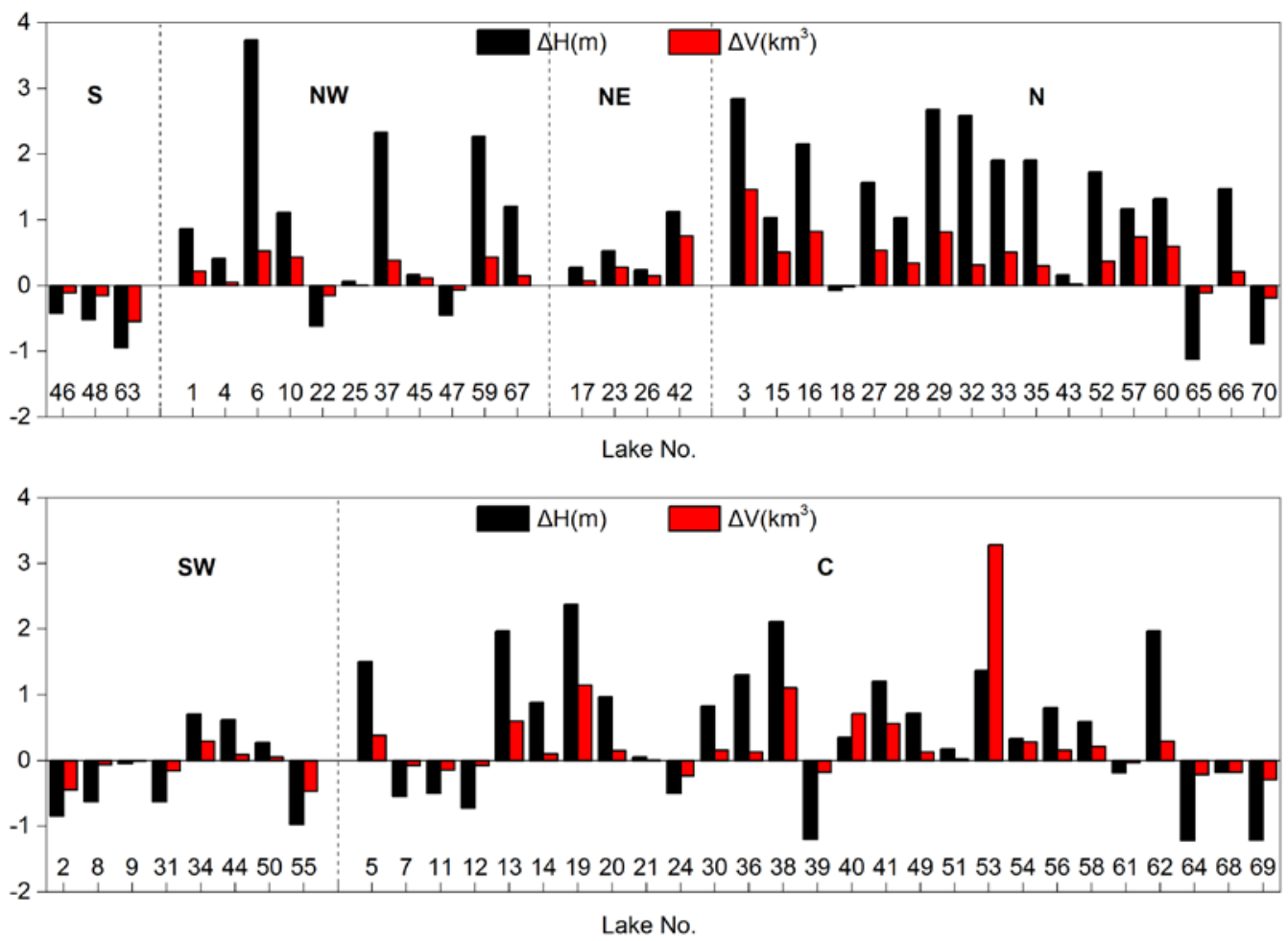

250

251

Figure 8: Lake level and storage change from 2010 to 2015

The increase in net water storage is estimated as $17.0 \times 10^{9} \mathrm{~m}^{3}$ from 2010 to 2015 . Figure

8 reveals that Aqqikkol (3), Dorsoidong Co (19), Migriggyangzham Co (38) and Siling Co (53)

all gained more than $1 \times 10^{9} \mathrm{~m}^{3}$, and contributed $41.2 \%$ of totalvolume gained.

\subsection{Comparison between different periods}

The level variations of 42 lakes are compared during two periods, i.e., 2003-2009 and 2010-2015. Figure 9 illustrated the distribution and change of 42 lakes. It is clear that almost all lakes kept rising (Fig. A1 \& Fig. 9) and the mean rising rate are almost the same, i.e. 0.33 and $0.32 \mathrm{~m} / \mathrm{yr}$ during two periods.

In sub-region NW and N, lakes maintained rising trend and the rising rates of two periods were comparable, such as Bangdag Co, Lixiodain Co, Memar Co (Fig. 10). Some lakes in subregion N, even arose more sharply, compared to 2003-2009. For instance, Aqqikkol lake arose 


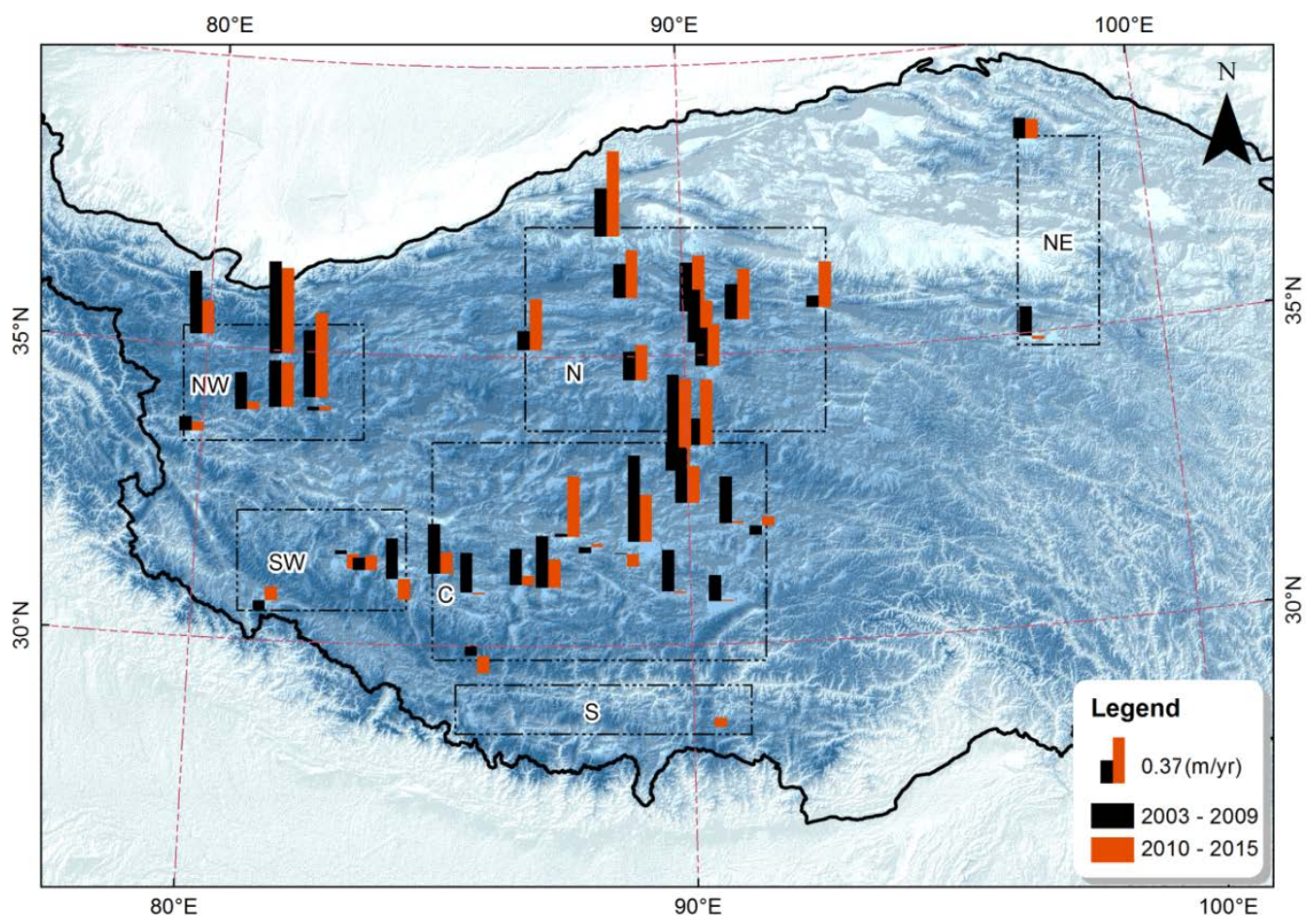

Figure 9: Map of lake level change rates during the periods of 2003-2009 and 20102015
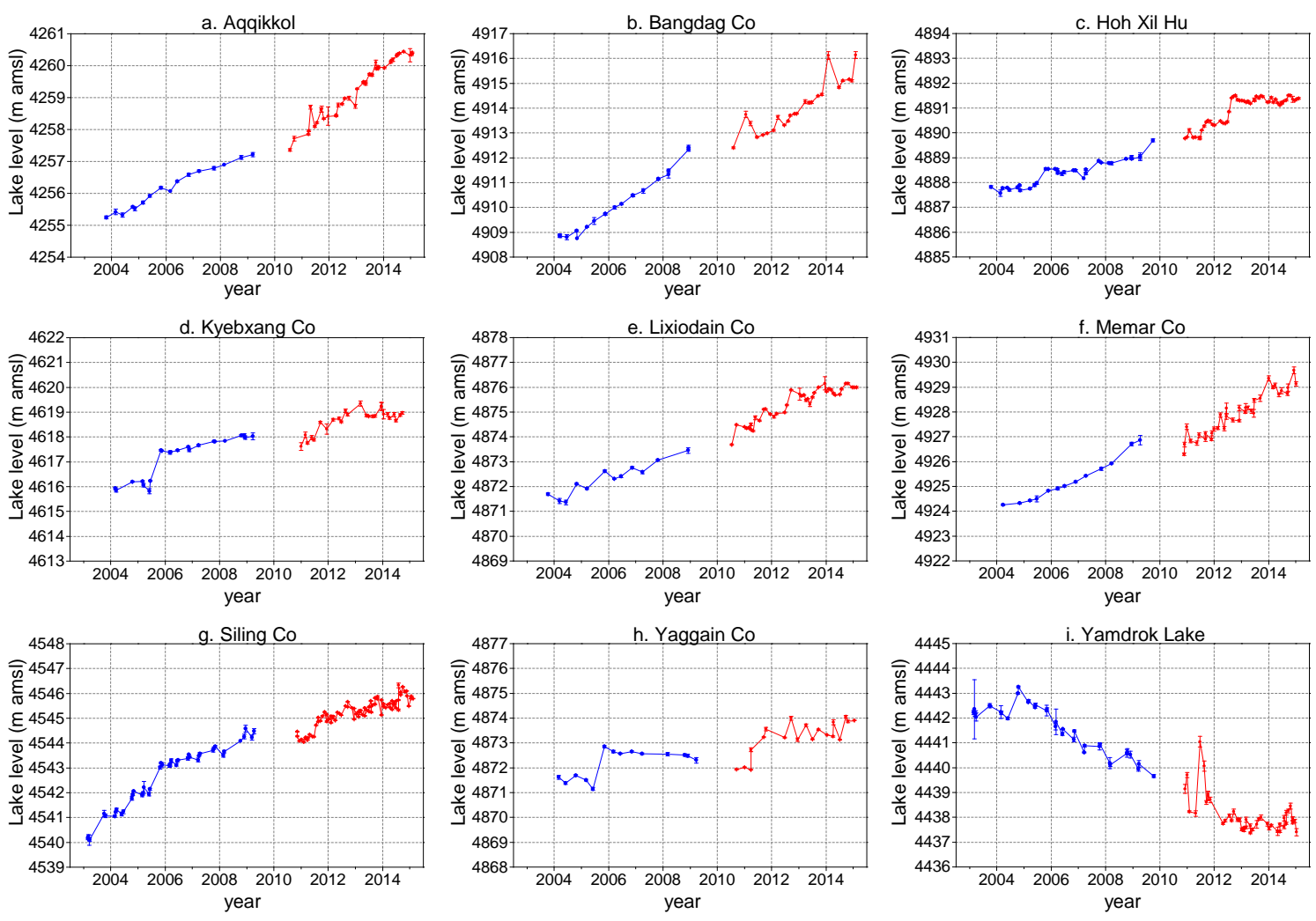
Figure 10: Evolution of lake levels for nine lakes during the period of 2003-2015 (ICESat time series in blue and Cryosat-2 time series in red)

Kyebxang Co and Yaggain Co experienced a similar rising process, i.e., an abrupt rising in 2005 followed by a relatively steady stage, and in recent five years, had a $\sim 2 \mathrm{~m}$ rising. Siling Co, the largest lake after Qinghai Lake on the TP, kept rising during the whole period (Fig. 10).

Twelve of the 42 lakes changed the evolution process from increase to decrease or vice versa. These lakes were mainly distributed in sub-region C and SW. Most of them are just slowing the rising trend, having a steady stage or slightly decreasing (Table A1). The only one kept significant declining is Yamdrok Lake which has declined $5 \mathrm{~m}$ during 2003-2015 (Fig. 10).

\section{Discussion}

Lakes on the TP are mainly affected by natural processes and most of them are closed lakes. The inflows include precipitation over the lake, surface runoff derived from precipitation and glacier/snow. The outflow is mainly evaporation. Thus, the lake water balance can be expressed as below:

$$
\Delta H=P+R-E \pm \varepsilon,
$$

where $\Delta \mathrm{H}$ is the lake level change, $\mathrm{P}$ is the precipitation over the lake, $\mathrm{R}$ is the depth of inflow derived from basin precipitation and glacier/snow meltwater, E is the evaporation over the lake, and $\xi$ is the sum of groundwater exchange and permafrost thawing recharge. All components are expressed as depth for lake in units of meter.

To investigate the potential factors contributing to lake level change, lake basin-wide climate normals and change rates of precipitation and temperature, supply coefficient, glacier ratio and basin elevation were regressed against level change rate for 54 endorheic lakes (Table 
290

291

293

294

3). In the following sub-sections, we will discuss the main potential factors in detail.

\subsection{Climate factors}

Precipitation (P) and evaporation (E) are the two most direct climatic factors affecting the lake level. For example, the coherent lake growth on the TP interior was mainly attributed to increased precipitation and decreased evaporation (Lei et al., 2014). Similarly, Song et al. (2015) also concluded that annual lake level variations were mainly related to precipitation and evaporation variability. Nevertheless, a recent case study shows that evaporation decrease just accounts for about $4 \%$ of the expansion of Nam Co (Ma et al., 2016). However, evaporation is closely related to temperature, wind, insolation and the duration of ice-free condition. Most of the previous studies did not consider the duration of lake evaporation, and moreover, potential evapotranspiration was used to calculate lake water balance instead of evaporation over lake. With the rising temperature, how lake evaporation changes is still not clear. As for temperature, it is indirectly influencing the lake change by melting glacier, snow and permafrost, and at the meantime, it will change the evaporation over lake and evapotranspiration over the basin.

In our study, lake level change rate is significantly related to annual precipitation change rate. Most of the lake basins show an increasing trend (Fig. 11), which results in more recharge to lakes. However, the abrupt rising of six lakes in sub-region N (Fig. 5), cannot be explained by increased precipitation. As we can see from Figure 5, the rise occurred over a period of about 2-7 months. If this was the result of increased rainfall, the precipitation amount in these months should be substantial, which is not found in the data.

On the other hand, level change rate is significantly correlated with temperature, especially autumn and winter temperature (Fig. 11). It reveals that lakes with higher change rate are 
located in lower temperature zones where permafrost is widely distributed. This may be explained by the permafrost thawing as reported by Li et al (2014). Moreover, level change rates are significantly and positively correlated to autumn temperature change rates and summer minimum temperature, while significantly and negatively correlated to winter temperature. Autumn temperature rising speeds the thawing of permafrost, and more water may be released to recharge the lakes by means of springs and/or groundwater. However, winter temperature is below zero, and the rising just accelerates the evapotranspiration process instead of increasing meltwater.
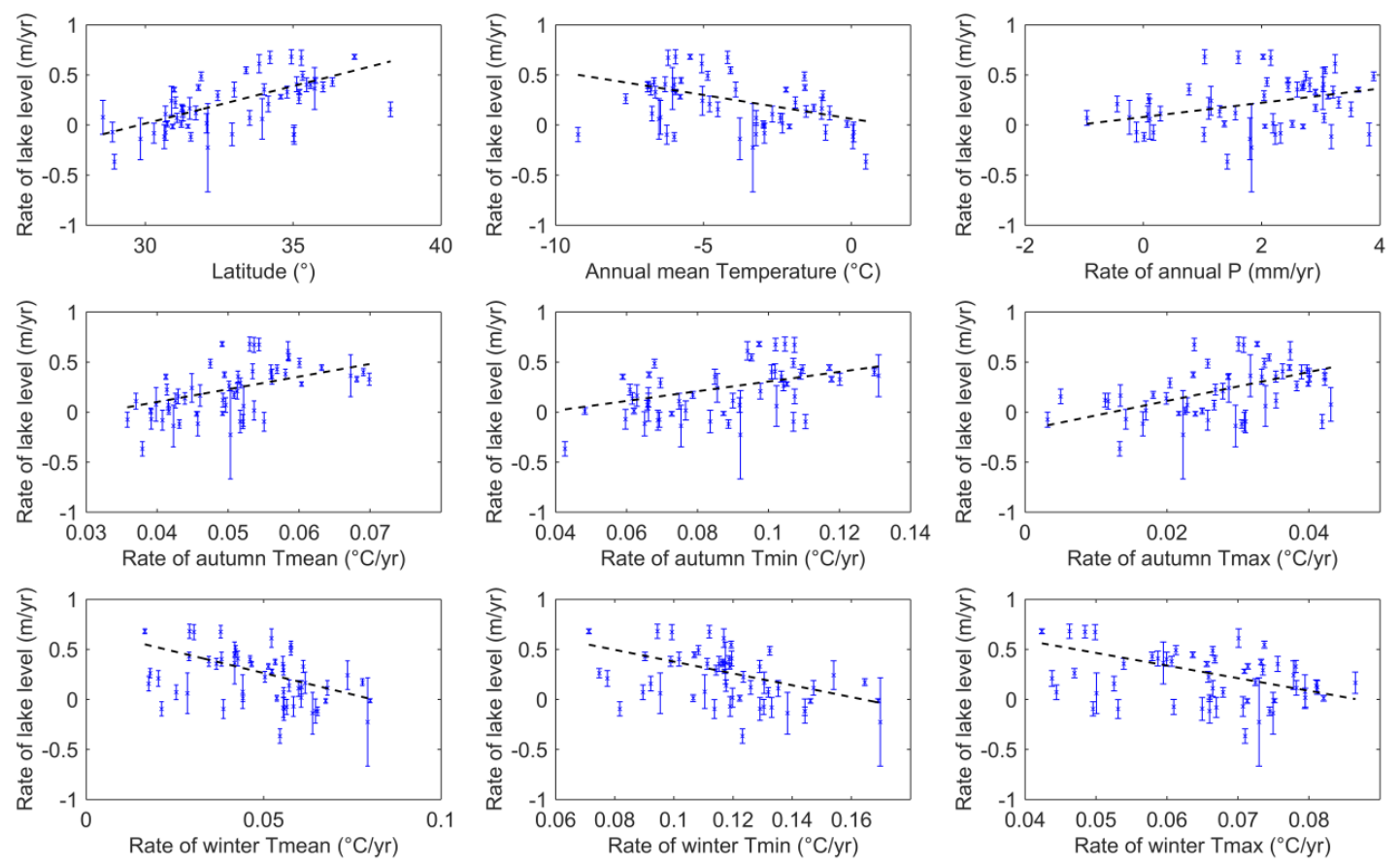

Figure 11: Correlation between different factors (x-axis) and lake level change rate (yaxis)

\subsection{Glacier meltwater}

Glacier meltwater is an important recharge source for lakes with glaciated headwaters, and

it is widely considered as the most crucial factor attributing to lake rising (Zhang et al., 2011). 
327 On the other hand, the study of Li et al.(2014) shows that glacier melt has a limited influence 328 on lake changes. For most lake basins the glacier ratio is very small and some are free of glaciers 329 (Table A1). In this study, the relationship between level change rate and glacier ratio was unclear.

330 Thus, in this study glacier meltwater is not found to be a global factor for the TP lakes even 331 though it contributes to net water balance for certain lakes.

\subsection{Permafrost}

Warming temperature leads to the degradation of permafrost, and may even lead to a breach of permafrost layer beneath lakes and thus result in exchange between lake and the subsurface(Smith et al., 2005). The repeated freeze-thaw cycles create increased porosity and permeability which may lead to better exchange conditions for supra-permafrost water (Cheng and Jin, 2012). Recently, Johansson et al. (Johansson et al., 2015) studied the interactions between lake, active layer and talik in a continuous permafrost catchment. In the northern region of the TP, continuous permafrost is well developed and lakes maintained rising in the past decade. Permafrost affects the lake balance, but it is still a challenge to estimate the quantity negatively correlated to temperature, which indicates that permafrost plays an important role in lake rising. This may be the reason of the abrupt rising of lakes in sub-region $\mathrm{N}$. significantly over short-time scales. Nevertheless, the geomorphological setting can influence a lake 
will merge when at highstand and separate at lowstand. Another case is discharge from one to another when the lake level reaches the elevation of the divide between them (Fig. A2). For example, Dorsoidong Co and Migriggyangzham Co are two lakes connected after rising. Dorsoidong Co and Migriggyangzham Co (also called Chibuzhang Co) are two large sister lakes. Using images from 1972 to 2015, we found that they were connected in 2005 (Fig. 12). Dorsoidong Co had a rapid increase during June 2005 to October 2005, when Migriggyangzham Co discharged to Dorsoidong Co through the divide. The divide (indicated by red circle in Fig. 12) of the pond connecting them is 4935 from SRTM DEM. Thus once the level of Migriggyangzham Co first reaches 4935 m, it will recharge Dorsoidong Co. This can be confirmed by the water level time series (Fig. 12). At the end of 2007, the levels of both lakes reached $4935.2 \mathrm{~m}$ and increased in lockstep. Therefore, the rising of Dorsoidong Co since 2005 is partially due to the discharge of Migriggyangzham Co. This phenomenon is also reported by other studies (Song and Sheng, 2016; Tseng et al., 2016). 


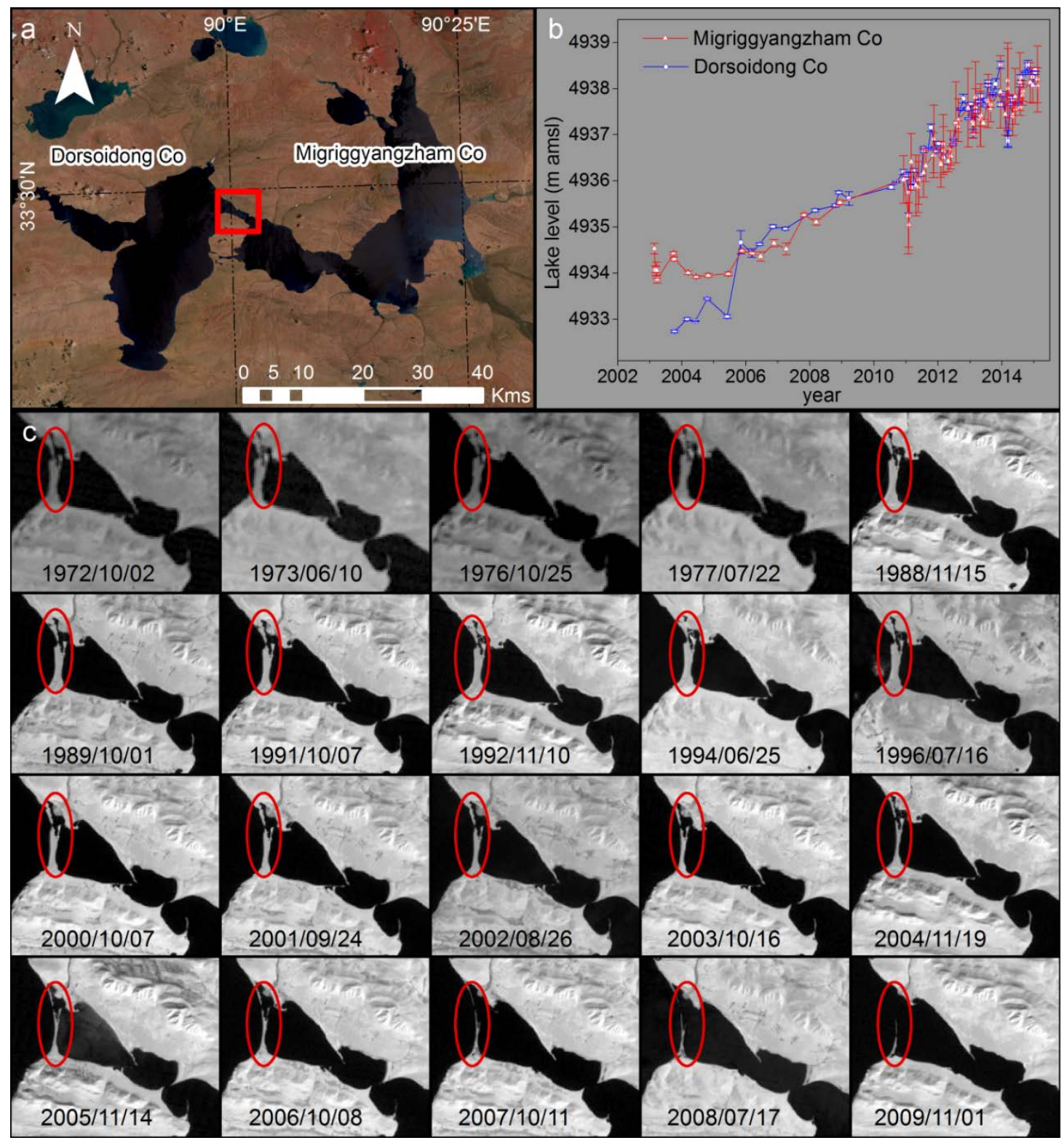

Figure 12: Maps of Dorsoidong Co and Migriggyangzham Co. a) lake location (red rectangle is shown in figure c; b) long-term time series; c) zoom-in view of the connection between two lakes on different dates (red ellipse indicates the pond connecting two lakes)

\subsection{Groundwater exchange}

Generally, groundwater exchange is not considered in a lake balance study. The reason is

twofold, one: the fine lake sediment and permafrost serve as impermeable layers and two: no 
371

exchange plays an important role which cannot be neglected. For example, Zhou et al. (2013) found that the inflow do not balance outflow if lake discharge is not considered, and inflow is more than outflow by $810-1220 \mathrm{~mm}$ one year.

In the southern region of the TP, permafrost zone is discontinuous and with limited areal extent and thickness (Cheng and Jin, 2012). The groundwater is closely linked to rivers and lakes. Andermann et al. (2012) found that groundwater contributes more than ice and snow in central Himalaya.

Groundwater discharge in the form of depression springs occurs widely in the northern part of the TP according to Wang and Dou (1998) and the first author encountered many hot springs during field work in 2012 and 2013.

Under climate change, glacier and permafrost respond heterogeneously. Considering the heterogeneity of topography and diversity of supply sources, different factors contribute to lakes change. Therefore, it is not possible to draw a conclusion at the TP scale.

\section{Conclusion}

In our study, 70 large lakes $\left(>100 \mathrm{~km}^{2}\right)$ were investigated. We find that $68.6 \%$ of the lakes experienced a rising in lake level. These lakes were mainly clustered in northwest and northern parts as well as scattered in the central part of the TP. It should be noted that $88 \%$ of the lakes in sub-region $\mathrm{N}$ (Northern part of the TP), were expanding drastically with an average rate of $0.374 \mathrm{~m} / \mathrm{yr}$. Nevertheless, of the $31.4 \%$ declining lakes, only 7 showed a decreasing rate greater than $0.1 \mathrm{~m} / \mathrm{yr}$. In conclusion, rising was the dominant changing trend of these lakes. The estimation of water storage change in these lakes is $17.6 \times 10^{9} \mathrm{~m}^{3}$ from 2010 to $2015,41.2 \%$ of 
392

393

which is contributed by Aqqikkol, Dorsoidong Co, Migriggyangzham Co and Siling Co.

Furthermore, compared with the change rates during 2003-2009, 28 of the 42 lakes maintained rising trend and their rates are comparable. Lakes in sub-region N and NW show a consistent rising with an average of about $5 \mathrm{~m}$ in the period of 2003-2015 although several lakes in sub-region $\mathrm{N}$ were steady in recent years.

By factor analysis, we discover that the temperature is closely related to lake level change rate and autumn and winter temperatures play opposite roles. Besides, the latitude is significantly related to level change rate. This new result may indicate that freeze-thaw processes of permafrost are driving forces behind observed lake change. More research is needed on the influence of permafrost. No coherent process exists for all lakes and the rising mechanism cannot be explained by one single factor.

In addition, compared to ICESat altimetry data, Cryosat-2 covers more lakes due to its dense distribution of ground tracks. The upcoming SAR altimetry missions (e.g. Sentinel-3 with a cycle period of 27 days) will be of value in monitoring lake level changes.

\section{Acknowledgements}

We thank the China Meteorological Administration, the European Space Agency (ESA) for providing meteorological data and CryoSat-2 data, respectively. Provision of ICESat lake level data by University of Bristol is also acknowledged. The first author thanks the funding support from China Scholarship Council. 
412 The details of lake number, name, location, change rates of different periods, etc. are listed in

413 Table A1 shows the correlation between other 26 factors and lake level change rage. Figure A2

414 illustrates the evolution of level during 2003 - 2015 for other 33 lakes. Cases of lakes with

415 potential recharge relationship are shown in Figure A3.
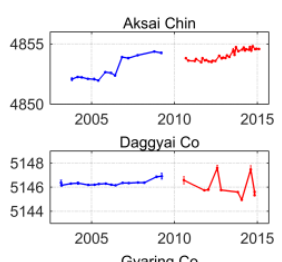

${ }_{4646}^{4650}{ }_{2005 \quad 2010}^{2015}$

4590 Mapam Yumco

\begin{tabular}{rrr}
\hline 2005 & 2010 \\
\hline & 2015 \\
\hline
\end{tabular}

P578 20015

4568

4966 $\left.4968\right|_{2005 \quad 2010} ^{2}$
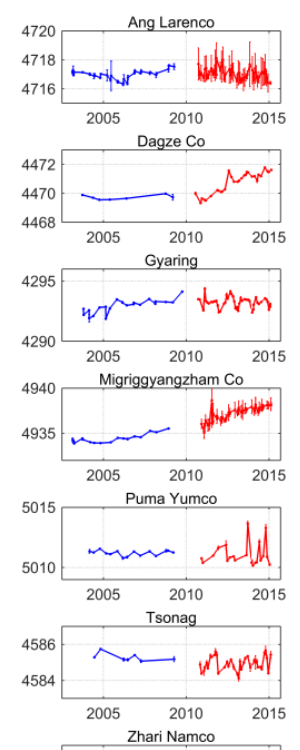

$\begin{array}{r}2005 \\ \quad \text { Zhari Namco } \\ \hline\end{array}$

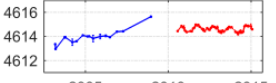

$4612 \stackrel{2005 \quad 2010 \quad 2015}{20}$
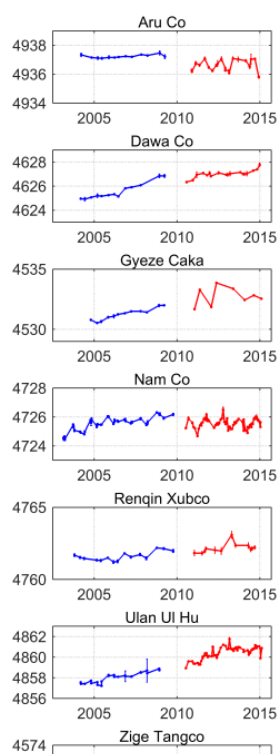

4574

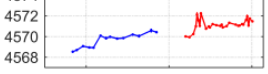

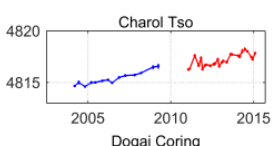
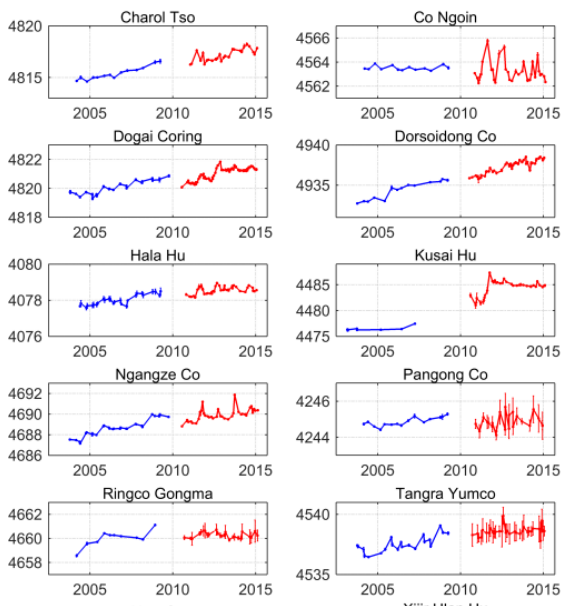

$4550 \underbrace{2010}_{2005} 2015$

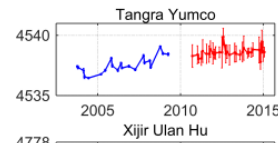

$\begin{array}{ccc}2005 & 2010 & 2015 \\ 4778 & \text { Xijir Ulan Hu }\end{array}$

2015

Figure A1: Correlation between other 26 factors and lake level change rate (appendix 418 to Fig. 8)
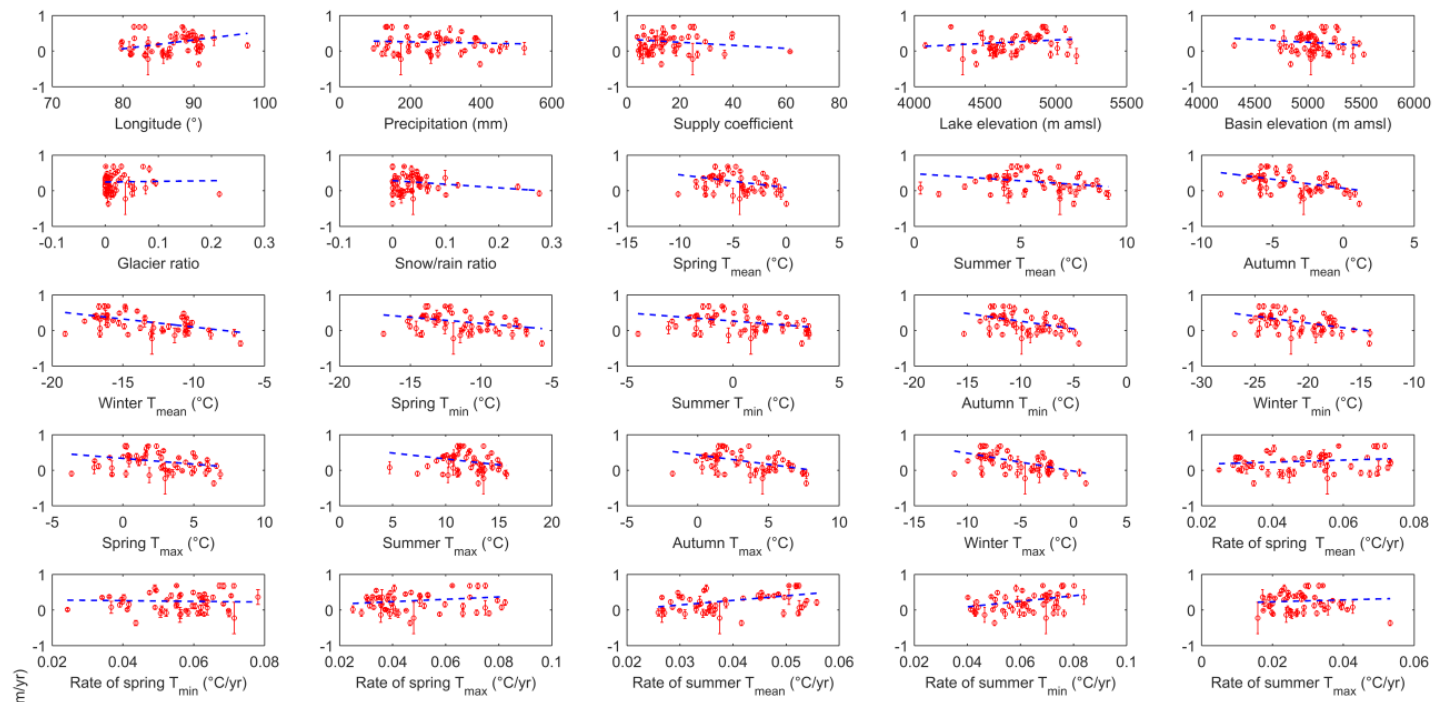
420 Figure A2: Evolution of lake levels during the period of 2003-2015 for other 33 lakes

421 (ICESat time series in blue and Cryosat-2 time series in red) (appendix to Fig. 10)
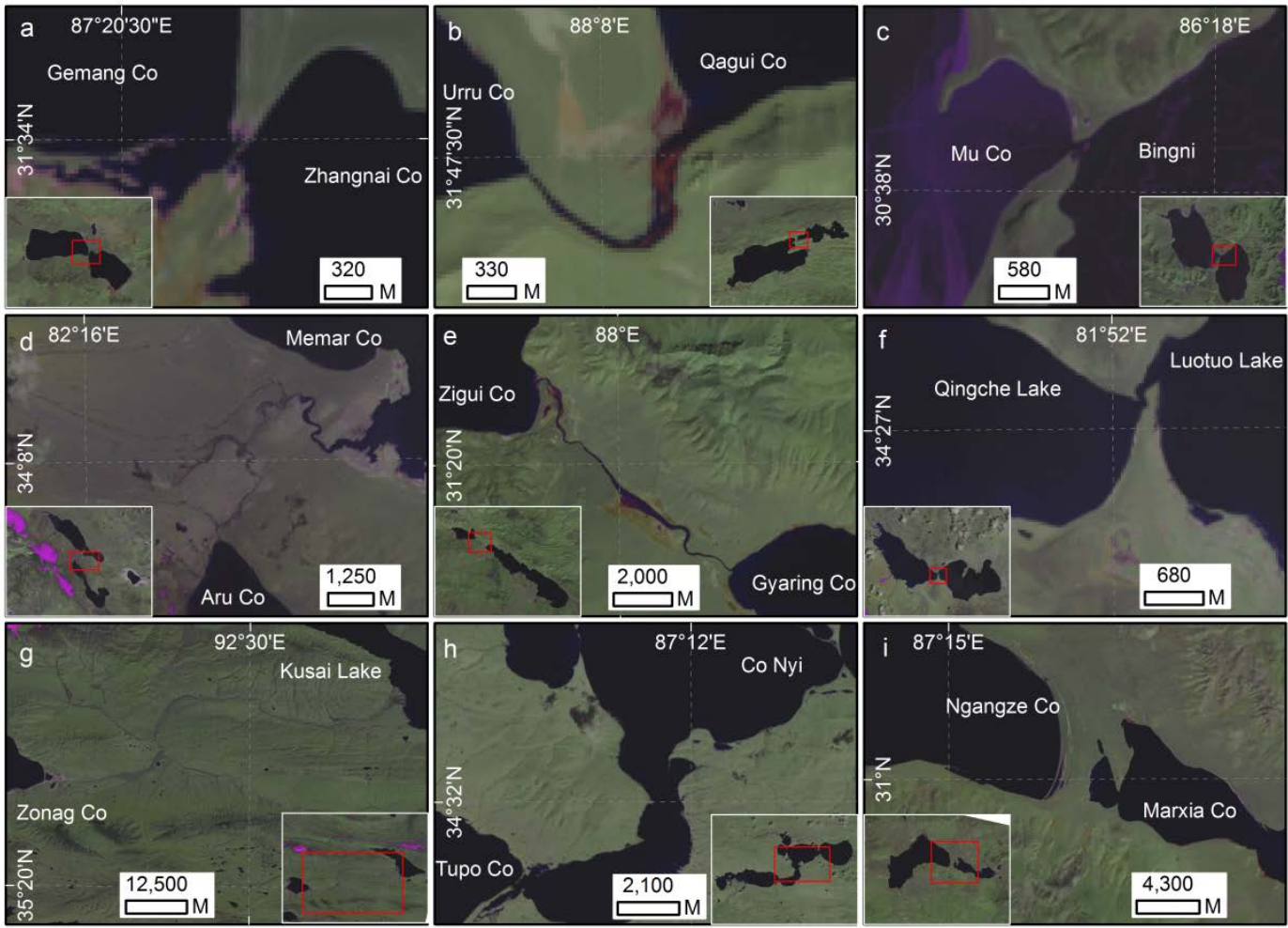

Figure A3: Cases of lakes with potential recharge relationship

\section{References}

Andermann, C., Longuevergne, L., Bonnet, S., Crave, A., Davy, P., Gloaguen, R., 2012. Impact of transient groundwater storage on the discharge of Himalayan rivers. Nat. Geosci. 5, 127-132. doi:10.1038/ngeo1356

Armitage, T.W.K., Davidson, M.W.J., 2014. Using the interferometric capabilities of the ESA CryoSat-2 mission to improve the accuracy of sea ice freeboard retrievals. IEEE Trans. Geosci. Remote Sens. 52, 529-536. doi:10.1109/TGRS.2013.2242082 
435

Birkett, C.M., 1995. The contribution of TOPEX/POSEIDON to the global monitoring of climatically sensitive lakes. J. Geophys. Res. 100, 25179. doi:10.1029/95JC02125

Cheng, G., Jin, H., 2012. Permafrost and groundwater on the Qinghai-Tibet Plateau and in northeast China. Hydrogeol. J. 21, 5-23. doi:10.1007/s10040-012-0927-2

Crétaux, J.-F., Abarca-del-Río, R., Bergé-Nguyen, M., Arsen, A., Drolon, V., Clos, G., Maisongrande, P., 2016. Lake Volume Monitoring from Space. Surv. Geophys. M. doi:10.1007/s10712-016-9362-6

Crétaux, J.F., Birkett, C., 2006. Lake studies from satellite radar altimetry. Comptes Rendus Geosci. 338, 1098-1112. doi:10.1016/j.crte.2006.08.002

European Space Agency, Mullar Space Science Laboratory, 2012. CryoSat Product Handbook DLFE-3605, 101.

Gao, L., Liao, J., Shen, G., 2013. Monitoring lake-level changes in the Qinghai-Tibetan Plateau using radar altimeter data (2002-2012). J. Appl. Remote Sens. 7, 73470. doi:10.1117/1.JRS.7.073470

Immerzeel, W.W., Van Beek, L.P.H., Bierkens, M.F.P., 2010. Climate change will affect the Asian water towers. Science (80-. ). 328, 1382-1385.

Jain, M., Andersen, O.B., Dall, J., Stenseng, L., 2015. Sea surface height determination in the Arctic using Cryosat-2 SAR data from primary peak empirical retrackers. Adv. Sp. Res. 55, 40-50. doi:10.1016/j.asr.2014.09.006 
Johansson, E., Gustafsson, L.-G., Berglund, S., Lindborg, T., Selroos, J.-O., Claesson Liljedahl, L., Destouni, G., 2015. Data evaluation and numerical modeling of hydrological interactions between active layer, lake and talik in a permafrost catchment, Western Greenland. J. Hydrol. 527, 688-703. doi:10.1016/j.jhydrol.2015.05.026

Kleinherenbrink, M., Ditmar, P.G., Lindenbergh, R.C., 2014. Retracking Cryosat data in the SARIn mode and robust lake level extraction. Remote Sens. Environ. 152, 38-50. doi:10.1016/j.rse.2014.05.014

Kleinherenbrink, M., Lindenbergh, R.C., Ditmar, P.G., 2015. Monitoring of lake level changes on the Tibetan Plateau and Tian Shan by retracking Cryosat SARIn waveforms. J. Hydrol. 521, 119-131. doi:10.1016/j.jhydrol.2014.11.063

Lei, Y., Yang, K., Wang, B., Sheng, Y., Bird, B.W., Zhang, G., Tian, L., 2014. Response of inland lake dynamics over the Tibetan Plateau to climate change. Clim. Change 125, 281290. doi:10.1007/s10584-014-1175-3

Li, Y., Liao, J., Guo, H., Liu, Z., Shen, G., 2014. Patterns and potential drivers of dramatic changes in Tibetan lakes, 1972-2010. PLoS One 9, e111890. doi:10.1371/journal.pone.0111890

Liao, J., Gao, L., Wang, X., 2014. Numerical simulation and forecasting of water level for qinghai lake using multi-altimeter data between 2002 and 2012. IEEE J. Sel. Top. Appl. Earth Obs. Remote Sens. 7, 609-622. doi:10.1109/JSTARS.2013.2291516

Liu, X., Lai, Z., Yi, C., Lei, Y., 2013. Long-term east-west asymmetry in monsoon rainfall on the Tibetan Plateau:Comment. Geology 41. doi:10.1130/G34548C.1 
Lu, C., Yu, G., Xie, G., 2005. Tibetan plateau serves as a water tower, in: Geoscience and Remote Sensing Symposium, 2005. IGARSS’05. Proceedings. 2005 IEEE International. IEEE, pp. 3120-3123.

Ma, N., Szilagyi, J., Niu, G.-Y., Zhang, Y., Zhang, T., Wang, B., Wu, Y., 2016. Evaporation variability of Nam Co Lake in the Tibetan Plateau and its role in recent rapid lake expansion. J. Hydrol. 537, 27-35. doi:10.1016/j.jhydrol.2016.03.030

Molnar, P., Boos, W.R., Battisti, D.S., 2010. Orographic controls on climate and paleoclimate of Asia: thermal and mechanical roles for the Tibetan Plateau. Annu. Rev. Earth Planet. Sci. 38, 77-102. doi:10.1146/annurev-earth-040809-152456

Nielsen, K., Stenseng, L., Andersen, O.B., Villadsen, H., Knudsen, P., 2015. Validation of CryoSat-2 SAR mode based lake levels. Remote Sens. Environ. 171, 162-170. doi:10.1016/j.rse.2015.10.023

O’Loughlin, F.E., Neal, J., Yamazaki, D., Bates, P.D., 2016. ICESat derived inland water surface spot heights. Water Resour. Res. n/a-n/a. doi:10.1002/2015WR018237

Phan, V.H., Lindenbergh, R., Menenti, M., 2012. ICESat derived elevation changes of Tibetan lakes between 2003 and 2009. Int. J. Appl. Earth Obs. Geoinf. 17, 12-22. doi:10.1016/j.jag.2011.09.015

Shen, Y., Chen, H., Xu, C., 2013. Remote Sensing Monitoring Study for the Tendency of Qinghai Lake’s Water Area in Last 41 Years. J. Water Resour. Res. 2, 309-315.

Smith, L.C., Sheng, Y., MacDonald, G.M., Hinzman, L.D., 2005. Disappearing Arctic Lakes. 
496

497

498

499

500

501

502

503

504

505

506

507

508

509

510

Song, C., Huang, B., Ke, L., 2015a. Heterogeneous change patterns of water level for inland lakes in High Mountain Asia derived from multi-mission satellite altimetry. Hydrol. Process. 29, 2769-2781. doi:10.1002/hyp.10399

Song, C., Huang, B., Ke, L., 2013. Modeling and analysis of lake water storage changes on the Tibetan Plateau using multi-mission satellite data. Remote Sens. Environ. 135, 25-35. doi:10.1016/j.rse.2013.03.013

Song, C., Huang, B., Ke, L., Richards, K.S., 2014. Seasonal and abrupt changes in the water level of closed lakes on the Tibetan Plateau and implications for climate impacts. J. Hydrol. 514, 131-144. doi:10.1016/j.jhydrol.2014.04.018

Song, C., Sheng, Y., 2016. Contrasting evolution patterns between glacier-fed and non-glacierfed lakes in the Tanggula Mountains and climate cause analysis. Clim. Change 135, 493507. doi:10.1007/s10584-015-1578-9

Song, C., Ye, Q., Cheng, X., 2015b. Shifts in water-level variation of Namco in the central Tibetan Plateau from ICESat and CryoSat-2 altimetry and station observations. Sci. Bull. 60, 1287-1297. doi:10.1007/s11434-015-0826-8

Song, C., Ye, Q., Sheng, Y., Gong, T., 2015c. Combined ICESat and CryoSat-2 Altimetry for Accessing Water Level Dynamics of Tibetan Lakes over 2003-2014. Water 7, 4685-4700. doi:10.3390/w7094685

Sørensen, L.S., Simonsen, S.B., Nielsen, K., Lucas-Picher, P., Spada, G., Adalgeirsdottir, G., 
Forsberg, R., Hvidberg, C.S., 2011. Mass balance of the Greenland ice sheet (2003-2008) from ICESat data - The impact of interpolation, sampling and firn density. Cryosphere 5, 173-186. doi:10.5194/tc-5-173-2011

Taube, C.M., 2000. Chapter 12: Three Methods for Computing the Volume of a Lake, in: Schneider, J.C. (Ed.), Manual of Fisheries Survey Mehtods II: With Periodic Updates. Michigan Department of Natural Resources.

Tseng, K.H., Chang, C.P., Shum, C.K., Kuo, C.Y., Liu, K.T., Shang, K., Jia, Y., Sun, J., 2016. Quantifying freshwater mass balance in the central Tibetan Plateau by integrating satellite remote sensing, altimetry, and gravimetry. Remote Sens. 8. doi:10.3390/rs8060441

Villadsen, H., Deng, X., Andersen, O.B., Stenseng, L., Nielsen, K., Knudsen, P., 2016. Improved inland water levels from SAR altimetry using novel empirical and physical retrackers. J. Hydrol. 537, 234-247. doi:10.1016/j.jhydrol.2016.03.051

Wan, W., Xiao, P., Feng, X., Li, H., Ma, R., Duan, H., Zhao, L., 2014. Monitoring lake changes of Qinghai-Tibetan Plateau over the past 30 years using satellite remote sensing data. Chinese Sci. Bull. 59, 1021-1035. doi:10.1007/s11434-014-0128-6

Wang, S., Dou, H., 1998. Lakes in China. Science Press, Beijing.

Wang, X., Gong, P., Zhao, Y., Xu, Y., Cheng, X., Niu, Z., Luo, Z., Huang, H., Sun, F., Li, X., 2013. Water-level changes in China's large lakes determined from ICESat/GLAS data. Remote Sens. Environ. 132, 131-144. doi:10.1016/j.rse.2013.01.005

Wu, G., Liu, Y., Zhang, Q., Duan, A., Wang, T., Wan, R., Liu, X., Li, W., Wang, Z., Liang, X., 

2007. The Influence of Mechanical and Thermal Forcing by the Tibetan Plateau on Asian Climate. J. Hydrometeorol. 8, 770-789. doi:10.1175/JHM609.1

Yanai, M., Li, C.F., 1994. Mechanism of Heating and the Boundary-Layer over the Tibetan $\begin{array}{llll}\text { Plateau. } & \text { Mon. } & \text { Weather } & \text { Rev. }\end{array}$ 0493(1994)122<0305:MOHATB >2.0.CO;2

Yao, T., Masson-delmotte, V., Gao, J., Yu, W., Yang, X., Risi, C., Sturm, C., Werner, M., Zhao, H., He, Y., Ren, W., 2013. A REVIEW OF CLIMATIC CONTROLS ON $\delta 18$ O IN PRECIPITATION OVER THE TIBETAN PLATEAU: OBSERVATIONS AND SIMULATIONS 525-548. doi:10.1002/rog.20023.1.INTRODUCTION

Zhang, G., Xie, H., Kang, S., Yi, D., Ackley, S.F., 2011. Monitoring lake level changes on the Tibetan Plateau using ICESat altimetry data (2003-2009). Remote Sens. Environ. 115, 1733-1742. doi:10.1016/j.rse.2011.03.005

Zhou, J., Wang, L., Zhang, Y., Guo, Y., Li, X., Liu, W., 2015. Exploring the water storage changes in the largest lake (Selin Co) over the Tibetan Plateau during 2003-2012 froma basin-wide hydrologicalmodeling. Water Resour. Res. 51, 1-27. doi:10.1002/2014WR016259

Zhou, S., Kang, S., Chen, F., Joswiak, D.R., 2013. Water balance observations reveal significant subsurface water seepage from Lake Nam Co, south-central Tibetan Plateau. J. Hydrol. 491, 89-99. doi:10.1016/j.jhydrol.2013.03.030 